\title{
EFICIENCIA ENERGÉTICA Y ECONÓMICA, BIENESTAR FAMILIAR Y PRODUCTIVIDAD EN AGROECOSISTEMAS TROPICALES
}

\author{
ENERGETIC AND ECONOMIC EFFICIENCY, FAMILY WELFARE AND PRODUCTIVITY IN \\ TROPICAL AGROECOSYSTEMS
}

\author{
R. Purroy-Vásquez ${ }^{1}$, F. Gallardo-López ${ }^{* 2}$, E. Ortega-Jiménez ${ }^{2}$, P. Díaz-Rivera ${ }^{2}$, Silvia López-Ortiz ${ }^{2}$, G. Torres-Hernández ${ }^{3}$
}

\begin{abstract}
${ }^{1}$ Instituto Tecnológico Superior de Tantoyuca, Desv. Camino Lindero Tametate S/N, Col. La Morita. Tantoyuca, Ver. 92100. ${ }^{2}$ Colegio de Postgraduados, Campus Veracruz. Km. 88.5 Carretera Federal Xalapa - Veracruz, Predio Tepetates, Municipio de Manlio Fabio Altamirano, Veracruz, México. ${ }^{3}$ Colegio de Postgraduados, Campus Montecillo. Km 36.5 Carretera MéxicoTexcoco, 56230. Montecillo, Texcoco, Edo. de México, México. (felipegl@colpos.mx)
\end{abstract}

\section{RESUMEN}

La seguridad alimentaria de una familia rural y de un país está ligada a las actividades agropecuarias, y deben efectuarse en equilibrio para alcanzar un desarrollo sustentable; esto incluye el adecuado manejo del recurso energético, económico y medioambiental dentro del Agroecosistema (AES). El objetivo de esta investigación fue determinar la relación entre el uso eficiente de la energía, la eficiencia económica, la productividad de los agroecosistemas, el autoconsumo y la línea de bienestar mínimo familiar en el municipio Paso de Ovejas. Se calcularon los costos de producción e ingresos para cada actividad agropecuaria en el AES y posteriormente se determinaron los índices de eficiencia económica y de uso de la energía. El cultivo de caña de azúcar mostró baja productividad; sin embargo, este cultivo contribuye con $0.61 \pm 0.42$ de la proporción de cobertura de la línea de bienestar mínimo, como resultado de los incentivos que el ingenio les ofrece a los productores de cańa. El $15 \%$ de la producción de maíz en la zona de lomeríos es utilizado para autoconsumo humano y $\mathbf{1 6} \%$ para el de animales. Sólo la leche en forma líquida o transformada (queso) participa en el autoconsumo, destinando para ello $4 \%$ de la producción en la zona de riego y $5 \%$ en lomerío. Los agroecosistemas con mayor superficie y con capacidad de riego son orientados a la siembra de cultivos de altos rendimientos energéticos, como la caña de azúcar en combinación con la cría de ganado bovino para mejorar la eficiencia económica. Esta actividad productiva permite a la familia rural solventar situaciones económicas coyunturales, ya que funciona como un ahorro familiar, concluyéndose que los productores implementan combinaciones de actividades productivas

* Autor responsable * Author for correspondence.

Recibido: marzo, 2014. Aprobado: abril, 2016.

Publicado como ARTÍCULO en ASyD 13: 513-527. 2016.
The food security of a rural family and of a country is linked to agricultural and livestock activities, and these must be carried out in equilibrium to reach sustainable development; this includes an adequate management of the energetic, economic and environmental resource within the Agroecosystem (AES). The objective of this study was to determine the relationship between efficient use of energy, economic efficiency, productivity of agroecosystems, auto-consumption, and the line of minimum family welfare in the municipality of Paso de Ovejas. The production costs and income were calculated for each agricultural/livestock activity in the AES and then the indexes of economic efficiency and energy use were determined. The cultivation of sugar cane showed low productivity; however, this crop contributes $0.61 \pm 0.42$ of the coverage proportion of the line of minimum welfare, as a result from the incentives that the sugar plant offers sugar cane producers. Of maize production in the hill zone, $15 \%$ is used for human autoconsumption and $16 \%$ for animals. Only the milk in liquid or transformed (cheese) form participates in auto-consumption, for which $4 \%$ of the production in the irrigation zone and $5 \%$ in the hill zone are destined. The agroecosystems with greater surface and with irrigation capacity are directed at crop sowing of high energetic yields, such as sugar cane in combination with cattle breeding to improve economic efficiency. This productive activity allows the rural family to afford temporary financial situations, since it functions as family saving, concluding that the producers implement combinations of productive activities in their agroecosystems, according to the availability of natural and financial resources, achieving differentiated coverages with regards to the line of minimum welfare.

Key words: agroecosystems, energy, line of minimum welfare and poverty. 
en sus agroecosistemas, de acuerdo con la disponibilidad de recursos naturales y económicos, logrando coberturas diferenciadas en relación con la línea de bienestar mínimo.

Palabras clave: agroecosistemas, energía, línea de bienestar mínimo pobreza.

\section{INTRODUCCIÓN}

$\mathrm{E}$ n América Latina existe una gran desigualdad en términos de la distribución del ingreso; el $10 \%$ más rico de la población concentra $32 \%$ de los ingresos totales, mientras que el $40 \%$ más pobre sólo percibe $15 \%$ (CEPAL, 2013a). En 2012, el porcentaje de pobreza de América Latina alcanzó a $28.2 \%$ de la población y la indigencia, o pobreza extrema, a $11.3 \%$. Estos porcentajes equivalen a 164 millones de personas en situación de pobreza, de las cuales 66 millones son pobres extremos (CEPAL, 2013b).

Es importante considerar que cada vez son menos los que producen alimentos para más personas. Es por ello que la Organización de la Naciones Unidas para la Alimentación y la Agricultura (FAO, 2015) en las recomendaciones finales del Seminario Regional sobre Agroecologia en América Latina y El Caribe indica que la producción agrícola se debe orientar hacia la sustentabilidad, asumiendo que los sistemas agroecológicos son más resilientes a los cambios climáticos y su desarrollo garantiza la soberanía alimentaria de los pueblos.

González (2011) expone que la dinámica evolutiva de los agroecosistemas, y con ella el cambio, es producto de la relación entre los dos polos de la relación socioecológica entre la población que los maneja y los recursos de que disponen.

Según Altieri et al. (2012), solamente aquellos estilos de agricultura que respeten los límites de la capacidad de uso de recursos naturales nacionales, regionales y locales permitirán a la población una adecuada soberanía alimentaria, energética y tecnológica, logrando producir la cantidad y calidad de alimento requerida dentro del escenario climático, energético, ecológico y económico de las próximas dos décadas.

En este sentido, es difícil pensar que con las riquezas naturales con que cuenta el estado de Veracruz en las zonas rurales existan familias campesinas en estado de pobreza; según González y

\section{INTRODUCTION}

$\mathrm{I}$ $\mathrm{n}$ Latin America, there is great inequality in terms of income distribution; the richest $10 \%$ of the population concentrate $32 \%$ of the total income, while the poorest $40 \%$ only receive $15 \%$ (CEPAL, 2013a). In 2012, the percentage of poverty in Latin America reached $28.2 \%$ of the population and destitution or extreme poverty, $11.3 \%$. These percentages are equivalent to 164 million people in situation of poverty, of which 66 million are in extreme poverty (CEPAL, 2013b).

It is important to consider that there are increasingly less people who produce foods for more people. This is why the Food and Agriculture Organization of the United Nations (FAO, 2015), in the final recommendations of the Regional Seminar on Agroecology in Latin America and the Caribbean, indicates that agricultural production must be directed towards sustainability, assuming that the agroecological systems are more resilient to climate changes and that their development guarantees the food sovereignty of peoples.

González (2011) describes how the evolutionary dynamics of agroecosystems, and with them change, is product of the relationship between the two poles of the socioecological relationship between the population that manages them and the resources they have access to.

According to Altieri et al. (2012), only those styles of farming that respect the capacity limits of the use of national, regional and local natural resources will allow the population an adequate dietary, energetic and technological sovereignty, managing to produce the quantity and quality of food required within the climate, energetic, ecological and economic scenario of the next two decades.

In this sense, it is difficult to think that even with the natural wealth present in the state of Veracruz in rural zones, there are peasant families in a state of poverty; according to González and Meneses (2015), this discrepancy between the agricultural and livestock production and the welfare of rural families is related to the inexistence of economic policies that protect the producer at the price level of agricultural and livestock products to guarantee them an adequate profitability that allows producers to obtain the necessary income to make the primary 
Meneses (2015), este desfase entre la producción agropecuaria y el bienestar de las familias rurales está relacionado con la inexistencia de políticas económicas que protejan al productor a nivel de precio de los productos agropecuarios, para garantizarle una adecuada rentabilidad que permita a los productores obtener los ingresos necesarios para hacer del sector primario una actividad sostenible financieramente y atractiva al mantenimiento de los niveles de producción; para ello, es necesario hacer un uso eficiente de la energía y de los recursos económicos que le permitan al productor superar la pobreza y alcanzar un desarrollo sustentable. Por estas razones, el objetivo de esta investigación fue determinar la relación entre el uso eficiente de la energía, así como la eficiencia económica y la productiva de los agroecosistemas con la línea de bienestar mínimo familiar, en el municipio Paso de Ovejas, Veracruz.

\section{Material y Métodos}

El estudio se realizó en el municipio de Paso de Ovejas, localizado en la parte central del estado de Veracruz, entre las coordenadas $19^{\circ} 17^{\prime} 12^{\prime \prime}$ $19^{\circ} 18^{\prime} 26^{\prime \prime} \mathrm{N}$ y $96^{\circ} 26^{\prime} 30^{\prime \prime}-96^{\circ} 27^{\prime} 16^{\prime \prime} \mathrm{O}$. La altitud varía de 40 a $280 \mathrm{~m}$ y tiene una superficie de 384.95 $\mathrm{km}^{2}$ (INAFED, 2002). El clima es cálido subhúmedo de subtipo $A_{0}$, que corresponde al más seco de los subhúmedos, por presentar una relación precipitación/temperatura $(\mathrm{P} / \mathrm{T})$ menor a 43.2, con lluvias en verano, mientras que el subtipo $\mathrm{Aw}_{1}$ corresponde también al tipo cálido subhúmedo, con régimen de lluvias en verano, pero con relación $\mathrm{P} / \mathrm{T}$ entre 55.3 y 43.2 (García, 2004).

En esta investigación la unidad de estudio fueron los agroecosistemas (AES) conformados por parcelas con actividades agropecuarias presentes en el municipio de Paso de Ovejas. Para establecer el marco muestral se utilizaron los padrones de productores beneficiarios de los programas de la Secretaría de Agricultura, Ganadería, Desarrollo Rural, Pesca y Alimentación (SAGARPA) del ciclo 2006-2007 (PROCAMPO, PROGAN y DIESEL) y el padrón de usuarios del Distrito de Riego número 35, La Antigua, de 2007.

Para efectos de este trabajo sólo se seleccionaron AES cuyas actividades agropecuarias principales eran: caña de azúcar (Saccharum officinarum L.), maíz (Zea mays L.) y bovinos (Bos taurus y Bos. indicu), estando sector a financially sustainable activity and attractive to maintaining the production levels; for this purpose, it is necessary to make an efficient use of the energy and the financial resources that allow the producer to overcome poverty and reach sustainable development. Therefore, the objective of this study was to determine the relationship between the efficient use of energy, as well as the economic and productive efficiency of agroecosystems with the line of minimum family welfare in the municipality of Paso de Ovejas, Veracruz.

\section{Materials and Methods}

The study was performed in the municipality of Paso de Ovejas, located in the central part of the state of Veracruz, between coordinates $19^{\circ} 17^{\prime} 12^{\prime \prime}$ - 19 $19^{\circ} 26^{\prime \prime}$ Latitude North and $96^{\circ} 26^{\prime} 30^{\prime \prime}-96^{\circ}$ $27^{\prime} 16^{\prime \prime}$ Longitude West. The altitude varies from 40 to 280 masl and it has a surface of $384.95 \mathrm{~km}^{2}$ (INAFED, 2002). The sub-humid warm climate of sub-type $\mathrm{Aw}_{0}$, which corresponds to the driest of the sub-humids because it presents a precipitation/ temperature $(\mathrm{P} / \mathrm{T})$ rate under 43.2 , with summer rains, while the sub-type $A w_{1}$ corresponds also to the sub-humid warm type, with a regime of summer rains, but with a $\mathrm{P} / \mathrm{T}$ rate between 55.3 and 43.2 (García, 2004).

In this research the study unit was agroecosystems (AES) made up of plots with agricultural and livestock activities present in the municipality of Paso de Ovejas. In order to establish the sampling framework, the census of producers who were recipients of programs from the Ministry of Agriculture, Husbandry, Rural Development, Fishing and Food (Secretaria de Agricultura, Ganadería, Desarrollo Rural, Pesca y Alimentación, SAGARPA) in the 2006-2007 cycle (PROCAMPO, PROGAN and DIESEL), and the census of users from Irrigation District number 35, La Antigua, from 2007, were used.

For the purpose of this study only AES whose main agricultural and livestock activities were sugar cane (Saccharum officinarum L.), maize (Zea mays L.) and cattle (Bos taurus and Bos. indicu), were selected, with them being individual or combined. The variable used for stratification in the sampling framework was the surface of the AES, filtering the producers' censuses under two criteria: the first was within each program, where it was verified that 
estas de manera individual o combinadas. La variable utilizada para la estratificación en el marco muestral fue la superficie de los AES, depurando los padrones de productores bajo dos criterios: el primero fue dentro de cada programa, donde se verificó que los productores pertenecieran al municipio; en caso de que se repitieran los nombres de los productores con la mismos AES sólo se seleccionó un registro; si tenían varios AES en el mismo ejido se totalizaron las hectáreas por productor; en caso de que tuvieran diferentes AES en distintos ejidos, también fueron totalizadas. El segundo criterio fue la selección entre programas; si los productores eran beneficiarios en varios programas con diferentes AES, se seleccionaron los de mayor superficie reportada.

La base de datos depurada constó de 1834 AES, que conformó el marco muestral $(\mathrm{N})$. Con base en la información recabada se determinó el tamaño de muestra con el método de muestreo aleatorio por estratos (Scheaffer et al., 1987). Para el diseño de la muestra se definieron cinco estratos de acuerdo con la superficie total por productor, resultando una muestra de 81 productores (Cuadro 1) a los que se les aplicó una entrevista entre junio y julio de 2007.

Se efectuó un registro de las entradas al AES, correspondiente a insumos agropecuarios, maquinaria y mano de obra (familiar y asalariada) para calcular los costos totales de producción por AES. Para determinar ingresos se cuantificó la producción por rubro, ya fuera que estuviese dirigida a la venta o al autoconsumo, de acuerdo con su ciclo de producción. Posteriormente, los datos de estas actividades se convirtieron a valores de energía mediante los factores de conversión propuestos por diversos autores (Pimentel, 1993; Mora-Delgado et al., 2007, Rathke et al., 2007; Valdés et al., 2009). the producers belonged to the municipality; in the case that the names of the producers with the same AES were repeated, only one record was selected; if they had several AES in the same ejido the total hectares per producer were used; in the case that they had different AES in different ejidos, they were also added. The second criterion was the selection between programs; if the producers were beneficiaries in several programs with different AES, those with greatest surface reported were selected.

The filtered database had 1834 AES, which made up the sampling framework $(\mathrm{N})$. Based on the information gathered, the size of the sample was determined with the random sampling method per strata (Scheaffer et al., 1987). For the design of the sample, five strata were defined according to the total surface per producer, resulting in a sample of 81 producers (Table 1) to whom interviews were applied between June and July of 2007.

A record of entries into the AES was carried out, corresponding to agricultural and livestock inputs, machinery and workforce (family and paid), in order to calculate the total production costs per AES. To determine the income, production was quantified per segment, whether it was directed to sale or to autoconsumption, according to their production cycle. Later, the data from these activities became values of energy through the conversion factors proposed by various authors (Pimentel, 1993; Mora-Delgado et al., 2007; Rathke et al., 2007; Valdés et al., 2009).

\section{VARIABLES ANALYZED}

\section{Economic efficiency per hectare (Eeha)}

The indexes of economic efficiency allow identifying the yield from resources used in the productive process. It was calculated by dividing the sum of the total annual gross income per hectare

Cuadro 1. Estratificación de AES de acuerdo a la superficie para determinación del tamaño de la muestra. Table 1. Stratification of the AES according to the surface to determine the size of the sample.

\begin{tabular}{|c|c|c|c|c|c|}
\hline Estratos & Muy chicos & Chicos & Medianos & Grandes & Muy Grandes \\
\hline Rangos & $0.10-1.75^{*}$ & $1.76-2.99^{*}$ & $3-4.99^{*}$ & $5.0-9.99^{*}$ & $>10^{*}$ \\
\hline Base datos $\left(\mathrm{N}_{\mathrm{i}}\right)$ & $\mathrm{N}_{1}=331$ & $\mathrm{~N}_{2}=383$ & $\mathrm{~N}_{3}=554$ & $\mathrm{~N}_{4}=351$ & $\mathrm{~N}_{5}=215$ \\
\hline Submuestra $\left(n_{i}\right)$ & $\mathrm{n}_{1}=14$ & $\mathrm{n}_{2}=17$ & $\mathrm{n}_{3}=24$ & $\mathrm{n}_{4}=16$ & $\mathrm{n}_{5}=10$ \\
\hline
\end{tabular}

*Tamaño de la parcela (ha). * Size of the plot (ha). 


\section{VARIABLES ANALIZADAS}

\section{Eficiencia económica por hectárea (Eeha)}

Los índices de eficiencia económica permiten identificar el rendimiento de los recursos utilizados en el proceso productivo. Se calculó al dividir la sumatoria del ingreso total bruto anual por hectárea (Ingtoha) generado en cada una de las actividades agropecuarias entre la sumatoria del costo total de producción por hectárea (Ctpha) por actividad.

$$
\text { Eeha }=\frac{\sum_{i=1}^{n} \text { Ingtoha }}{\sum_{i=1}^{n} \text { Ctpha }}
$$

\section{Eficiencia en el uso de la energía por hectárea} (EAha)

La eficiencia en el uso de la energía por hectárea $(E \Delta h a)$ determina el nivel de manejo de los recursos energéticos dentro de los procesos productivos en los agroecosistemas. Para su cálculo se dividió la sumatoria de la producción total de energía por hectárea (Pt $\Delta h a)$ generada en la i-ésima actividad agropecuaria, entre la sumatoria de la energía invertida por hectárea $(i n v \Delta h a)$ en la i-ésima actividad en un periodo de un año.

$$
E \Delta h a=\frac{\sum_{i=1}^{n} P t \Delta h a}{\sum_{i=1}^{n} i n v \Delta h a}
$$

\section{Productividad}

Se entiende como la relación entre la producción obtenida por un sistema de producción o servicios y los recursos utilizados para obtenerla. Se planteó la determinación de la productividad económica y energética de los sistemas a través de indicadores.

\section{Indicadores de productividad económica (Ipreag)}

La productividad económica nos permite determinar el comportamiento productivo del agroecosistema (Cuadro 2) en pesos (\$) en relación con
(Ingtoha) generated in each one of the agricultural/ livestock activities, by the sum of the total production cost per hectare (Ctpha) per activity.

$$
\text { Eeha }=\frac{\sum_{i=1}^{n} \text { Ingtoha }}{\sum_{i=1}^{n} \text { Ctpha }}
$$

Efficiency in the use of energy per hectare $(E \Delta h a)$

The efficiency in the use of energy per hectare $(E \Delta h a)$ determines the level of management of the energetic resources within the productive processes in agroecosystems. For its calculation, the sum of the total energy production generated per hectare $(P t \Delta h a)$ was divided by the i-th agricultural/livestock activity, by the sum of the energy invested per hectare (inv $\Delta h a$ ) in the i-th activity during a period of one year.

$$
E \Delta h a=\frac{\sum_{i=1}^{n} P t \Delta h a}{\sum_{i=1}^{n} i n v \Delta h a}
$$

\section{Productivity}

It is understood as the relationship between the production obtained by a system of production or services and the resources used to obtain it. The determination of the financial and energetic productivity of the systems through indicators was suggested.

\section{Economic productivity indicators (Ipreag)}

Economic productivity allows us to determine the productive behavior of the agroecosystem (Table 2 ) in pesos $(\$)$ with regards to work units (\$ Man hours ${ }^{-1}$ ) and energy $\left(\$ \mathrm{MJ}^{-1}\right)$.

\section{Indicators of energetic productivity (Ipr $\Delta a g r)$}

Energetic productivity allows us to determine the productive behavior of the agroecosystem (Table 3 ) in megajoules (MJ). For its determination, the methodology proposed by Denoia et al. (2006) used when calculating the energetic productivity per unit of work (MJ Man hours ${ }^{-1}$ ) and monetary $\left(\mathrm{MJ}^{-1}\right)$. 
Cuadro 2. Variables usadas para calcular los indicadores de productividad económica de los agroecosistemas. Table 2. Variables used to calculate the indicators of economic productivity of agroecosystems.

\begin{tabular}{llll}
\hline Definición & Variable & Sub-variables & Unidades \\
\hline
\end{tabular}

Productividad económica por unidad de energía invertida en el agroecosistema

Productividad económica del trabajo en el agroecosistema

$$
P e \Delta=\frac{\sum_{i=1}^{n} P e h a}{\sum_{i=1}^{n} \Delta i n v h a}
$$

$$
P e t=\frac{\sum_{i=1}^{n} P e h a}{\sum_{i=1}^{n} H h a}
$$

Peha: Productividad económica del agroecosistema por hectárea de la i-ésima actividad

$\triangle$ invha: Total de energía invertida por hectárea en la i-ésima actividad

Peha: Productividad económica del agroecosistema por hectárea de la i-ésima actividad

Hha: Horas hombre por hectárea en la i-ésima actividad (en actividades manuales) unidades de trabajo ( $\$$ Horas hombre ${ }^{-1}$ ) y energía $(\$$ $\left.\mathrm{MJ}^{-1}\right)$.

\section{Indicadores de productividad energética

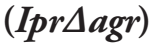

La productividad energética nos permite determinar el comportamiento productivo del agroecosistema (Cuadro 3) en megajoules (MJ). Para su determinación se utilizó la metodología propuesta por Denoia et al. (2006) al calcular la productividad energética por unidad de trabajo (MJ Horas hombre $^{-1}$ ) y monetaria $\left(\mathrm{MJ} \$^{-1}\right)$.

\section{Índice de biodiversidad agropecuaria}

Para obtener el índice de biodiversidad agropecuaria se calculó el índice de diversidad de Shannon (Shannon y Weaver, 1963). Este modelo toma en cuenta el número de subsistemas agrícolas y la distribución de la superficie para obtener la biodiversidad agropecuaria. Cuando el índice es alto existe mayor diversidad y alta incertidumbre (Gallardo-López et al., 2002; Salgado-Mora et al., 2007; Cirujeda et al.. 2008).

$$
H^{\prime}=-\sum\left[\rho_{i}\left(\log \rho_{i}\right)\right]
$$

\section{Index of agricultural/livestock biodiversity}

To obtain the index of agricultural/livestock biodiversity, the Shannon diversity index was calculated (Shannon and Weaver, 1963). This model takes into account the number of agricultural sub-systems and the distribution of the surface to obtain the agricultural/livestock biodiversity. When the index is high there is greater diversity and high uncertainty (Gallardo et al., 2002; Salgado-Mora et al., 2007; Cirujeda et al., 2008).

$$
H^{\prime}=-\sum\left[\rho_{i}\left(\log \rho_{i}\right)\right]
$$

where: $\rho_{\mathrm{i}}: \mathrm{n}_{\mathrm{i}} / \mathrm{N} ; H^{\prime}:$ diversity; $\mathrm{n}:$ surface assigned to each agricultural/livestock sub-system; $\mathrm{N}$ : total surface of the agroecosystem.

\section{Auto-consumption}

For auto-consumption $(A c)$, the Leite (2004) definition was used, which states that the study of auto-consumption is limited exclusively to food production; this is the part of the agricultural/ livestock production destined to feed the members of the family and the animals, deducing from this 
Cuadro 3. Variables usadas para construir el índice de productividad energética de los agroecosistemas. Table 3. Variables used to develop the index of energetic productivity of the agroecosystems.

\begin{tabular}{|c|c|c|c|}
\hline Definición & Variable & Sub-variables & Unidades \\
\hline $\begin{array}{l}\text { Productividad energética por costo de } \\
\text { producción del agroecosistema }\end{array}$ & $P \Delta \$=\frac{\sum_{i=1}^{n} P t \Delta h a}{\sum_{i=1}^{n} i n v \$ h a}$ & $\begin{array}{l}\text { Pt } \Delta \text { ha: } \text { Producción total de energía por } \\
\text { hectárea de la i-ésima actividad } \\
\text { invha: Inversión total por hectárea de la } \\
\text { i-ésima actividad }\end{array}$ & $\mathrm{MJ} \$^{-1}$ \\
\hline $\begin{array}{l}\text { Productividad energética del trabajo en el } \\
\text { agroecosistema }\end{array}$ & $P \Delta t=\frac{\sum_{i=1}^{n} P t \Delta h a}{\sum_{i=1}^{n} H h a}$ & $\begin{array}{l}\text { Pt } \Delta \boldsymbol{b a} \text { : Producción total de energía por } \\
\text { hectárea de la i-ésima actividad } \\
\text { Hha: Horas hombre por hectárea en la i-ésima } \\
\text { actividad (en actividades manuales). }\end{array}$ & $\mathrm{MJ} \mathrm{hh}^{-1}$ \\
\hline
\end{tabular}

donde: $\rho_{\mathrm{i}}: \mathrm{n}_{\mathrm{i}} / \mathrm{N} ; H^{\prime}:$ diversidad; $\mathrm{n}$ : superficie asignada a cada subsistema agropecuario; $\mathrm{N}$ : superficie total del agroecosistema.

\section{Autoconsumo}

Para el autoconsumo $(A c)$ se utilizó la definición de Leite (2004), la cual dice que el estudio del autoconsumo se limita exclusivamente a la producción de alimentos; esta es la parte de la producción agropecuaria destinada a alimentar a los miembros de la familia y a los animales, deduciendo de esta producción las partes relativas a la comercialización, donación o pérdida. En su cálculo se cuantificó el total de producto y a los subproductos obtenidos en el AES se les restó la cantidad que el productor utiliza para el consumo familiar; posteriormente se procedió a calcular qué porcentaje representaba (Gallardo et al., 2002).

\section{Porcentaje de cobertura de la línea de bienestar mínimo (Pcober)}

Para determinar la proporción de cobertura de la línea de bienestar mínimo (Pcober), primero se calculó el costo de la Canasta Normativa de Satisfactores Esenciales (CNSE) a través de la ecuación lineal ajustada por Boltvinik y Marín (2003) del cuadro elaborado por Marín (2002) para el cálculo del costo de las variables bienes familiares $(\mathrm{BF})$ y bienes individuales (BI), a partir de los requerimientos de la Coordinación General del Plan Nacional de Zonas Deprimidas (COPLAMAR) en la cual se consideran todos los satisfactores esenciales requeridos por un hogar, los production the parts related to commercialization, donation or loss. In its calculation the total of the product was quantified and the amount that the producer used for family consumption was subtracted from the sub-products obtained in the AES; then, the percentage it represented was calculated (Gallardo et al., 2002).

\section{Percentage of coverage of the line of minimum welfare (Pcober)}

In order to determine the proportion of coverage of the line of minimum welfare (Pcober), the cost of the Normative Basket of Essential Satisfiers (Canasta Normativa de Satisfactores Esenciales, CNSE) was first calculated through the linear equation adjusted by Boltvinik and Marín (2003) from the table elaborated by Marín (2002) for the calculation of the cost of the variables family goods (FG) and individual goods (IG), based on the requirements of the General Coordination of the National Plan for Depressed Zones (Coordinación General del Plan Nacional de Zonas Deprimidas, COPLAMAR) in which all the essential satisfiers required by a household are considered, the costs equivalent to those of an adult male which counts as the unit are the following: adult woman 0.81 , boy 0.58 , girl 0.54 , male baby 0.43 and female baby 0.43 .

$$
C N S E=37184+7842 p+24724 a e
$$

where: CNSE: Cost of the Normative Basket of Essential Satisfiers, ae: sum of equivalent adult units, 
costos equivalentes al de un varón adulto que cuenta como la unidad son los siguientes: mujer adulta 0.81 , niño 0.58 , niña 0.54 , bebé masculino 0.43 y bebé femenino 0.43 .

$$
C N S E=37184+7842 p+24724 a e
$$

donde: CNSE: Costo de la Canasta Normativa de Satisfactores Esenciales, ae: Sumatoria de unidades de adulto equivalente, $p$ : número de personas en el hogar. ${ }^{*}$ Los valores constantes están actualizados a junio de 2007.

Posteriormente, se calculó en qué proporción el ingreso neto anual generado en las actividades agropecuarias en el agroecosistema permite a cada familia alcanzar o superar la línea de bienestar mínimo.

$\mathrm{El}$ ingreso neto agropecuario (Inetoagr) se calculó totalizando los ingresos brutos generados de las actividades agropecuarias efectuadas en los agroecosistemas, incluyendo el $A c$, y a continuación se le restaron los costos totales de las actividades agropecuarias.

$$
\text { Pcober }=\frac{\text { Inetoagr }}{\text { CNSE }}
$$

\section{Análisis estadístico}

Se utilizó la técnica multivariada de correlación canónica, con la finalidad de conocer cuáles de los indicadores de eficiencia energética económica y de productividad de los agroecosistemas contribuyen a superar la línea de bienestar mínimo (LBM). Las variables independientes o de eficiencias fueron: zona, superficie, índice de biodiversidad, eficiencia energética, eficiencia económica, productividad energética por dinero invertido, productividad económica por energía invertida, productividad de trabajo por energía invertida y productividad de trabajo por dinero invertido. Las variables dependientes o sociales fueron: proporción de cobertura de la línea de bienestar mínimo y la de autoconsumo. Para ello se utilizó el programa estadístico Statistica ${ }^{\circledR}$ versión 6 (Stat-Soft Inc, 2003) y Microsoft Office Excel $2007^{\circ}$.

\section{Resultados y Discusión}

\section{Autoconsumo en los agroecosistemas}

Las parcelas en las zonas de riego tienen una superficie de 6.90 \pm 9.9 ha, ligeramente superior a las $p$ : number of people in the household. ${ }^{*}$ The constant values are updated up to June 2007.

Later, we calculated in what proportion the net annual income generated through the agricultural and livestock activities in the agroecosystem allows each family to reach or exceed the line of minimum welfare.

The net agricultural/livestock income (Inetoagr) was calculated by adding up the gross income generated from the agricultural/livestock activities carried out in the agroecosystems, including the $A c$, and next the total costs of the agricultural/livestock activities were subtracted.

$$
\begin{aligned}
& \text { Pcober }=\frac{\text { Inetoagr }}{\text { CNSE }} \\
& \text { Statistical analysis }
\end{aligned}
$$

The multivariate technique of canonical correlation was used, with the aim of understanding which of the indicators of economic energetic efficiency and of productivity of the agroecosystems contribute to exceeding the line of minimum welfare (LMW). The independent variables or of efficiency were: zone, surface, biodiversity index, energetic efficiency, economic efficiency, energetic productivity per money invested, economic productivity per energy invested, work productivity per energy invested, and work productivity per money invested. The dependent or social variables were: proportion of coverage of the line of minimum welfare and of auto-consumption. For this purpose, the statistical software Statistica ${ }^{\oplus}$ version 6 (Stat-Soft Inc, 2003) and Microsoft Office Excel $2007^{\circ}$ were used .

\section{Results AND Discussion}

\section{Auto-consumption in the agroecosystems}

The plots in the irrigation zones have a surface of 6.90 \pm 9.9 ha, slightly higher than those located in the hill zones, with an area of $5.81 \pm 9.3$ ha. Auto-consumption $(A c)$ is observed primarily in the agroecosystems where the activities of cattle breeding and maize sowing are carried out, directing part of the production to $A c$ and selling the excess (milk, cheese and maize), result that coincides with what was reported by Perales et al. (2005) where maize is a 
ubicadas en la zona de lomeríos, con un área de $5.81 \pm 9.3$ ha. El autoconsumo $(A c)$ se observa principalmente en los agroecosistemas donde se realizan las actividades de cría de bovinos y siembra de maíz, orientando parte de la producción al $A c$ y venden el excedente (leche, queso y maíz), resultado que coincide con lo reportado por Perales et al. (2005) donde el maíz es una fuente de alimentación, así como de ingreso, identidad cultural y condición social, y parte de una red de seguridad alimentaria de la familia rural campesina. En los AES dedicados a la producción de caña de azúcar y frutas no se evidencia $A c$ debido a las características de estos productos. En el caso del componente maíz, en la zona de riego, 15 $\%$ de la producción se utiliza para el Ac (humano y animal), mientras que en la de lomeríos es de $16 \%$. La familia campesina obtiene leche y carne (animales en pie) del componente bovino, pero solo la leche en forma líquida o transformada (queso) participa en el $A c$, con valores de $4 \%$ en la zona de riego y $5 \%$ de la producción de leche en lomerío. El 6\% de la leche es utilizada en forma de queso para la alimentación de la familia rural en la zona de riego, y en $8 \%$ en el lomerío; estos valores son similares a los reportados por Jiménez et al. (2008), quienes estimaron que $81 \%$ de los productores realizan autoconsumo y representan $4 \%$ del volumen de producción diaria.

Según Brunett et al. (2005), gran parte de la producción de leche es vendida a los "boteros" o "lecheros", quienes se encargan de comercializarla en las comunidades aledańas a los agroecosistemas; en otros casos la producción de leche es absorbida por los "queseros", los cuales la recolectan y la transforman en queso fresco. El excedente de la producción en los agroecosistemas se destina al $A c$, ya sea en forma líquida o como queso. Quintos y Quispe (2004) reportaron que generalmente en las pequeñas unidades de producción una parte importante de los productos (leche, carne, estiércol o animales) son destinados a la venta y el excedente para el $A c$; la familia rural trata de mejorar el estado nutricional de sus miembros a través de esta práctica.

\section{Relación en el uso eficiente de la energía, eficiencia económica, por zona y por actividad productiva con la proporción de la cobertura de la línea de bienestar mínimo}

De los 81 productores encuestados en el municipio de Paso de Ovejas, 50 poseen parcelas localizadas en el source of food, as well as of income, cultural identity and social condition, and part of a network of food security for the peasant rural family. In the AES devoted to sugar cane and fruit tree production the $A c$ is not made evident due to the characteristics of these products. In the case of the maize component, in the irrigation zone, $15 \%$ of the production was used for Ac (human and animal), while in the hill zone $16 \%$. The peasant family obtains milk and meat (standing animals) from the bovine component, but only milk in liquid or transformed form (cheese) participate in the $A c$, with values of $4 \%$ in the irrigation zone and $5 \%$ of the milk production in the hill zone. Of the milk, $6 \%$ is used in the form of cheese for the rural family's diet in the irrigation zone, and $8 \%$ in the hill zone; these values are similar to those reported by Jiménez et al. (2008), who estimated that $81 \%$ of the producers carry out auto-consumption and represent $4 \%$ of the daily production volume.

According to Brunett et al. (2005), a large part of milk production is sold to "boteros" or "lecheros", who are in charge of selling it in the communities adjacent to the agroecosystems; in other cases, milk production is absorbed by "queseros", who collect it and transform it into fresh cheese. The surplus production in agroecosystems is destined to $A c$, whether in liquid form or as cheese. Quintos and Quispe (2004) report that generally in small-scale production units, an important part of the products (milk, meat, manure or animals) are destined to the sale, and the surplus to $A c$; the rural family tries to improve the nutritional state of its members through this practice.

\section{Relation of the efficient use of energy, economic efficiency, by zone and by productive activity with the proportion of coverage of the line of minimum welfare}

Of the 81 producers surveyed in the municipality of Paso de Ovejas, 50 own plots located in Irrigation District $035 \mathrm{La}$ Antigua, of which $84 \%$ have cultivating sugar cane as main activity, which requires large quantities of water. In that sense, Parra (1989) reported that the climate factor that limits most the sugar cane production in the state of Veracruz is the distribution of rain precipitation, since the temperature of the state does not affect the development of the crop. As can be seen in Table 
Distrito de Riego 035 La Antigua, de los cuales, $84 \%$ tiene como actividad principal el cultivo de caña de azúcar, la cual requiere grandes cantidades de agua. Parra (1989) reportó que el factor climático que más limita a la producción de cańa de azúcar en el estado de Veracruz es la distribución de la precipitación pluvial, ya que la temperatura del estado no afecta el desarrollo del cultivo. Como se puede ver en el Cuadro 4, este presentó los valores más altos del uso eficiente de energía, resultados semejantes a lo reportado por Markos (2007) con la caña de azúcar como cultivo altamente productor de energía. La eficiencia de estos es elevada, en relación con la eficiencia presentada por otros sistemas de producción, como el de frutales, la cual es cercana a uno (Gliessman, 2001). La caña de azúcar tiene una baja productividad y, por consiguiente, el productor obtiene ingresos moderados por esta actividad en el AES; este cultivo contribuye con $0.61 \pm 0.42$ de la proporción de cobertura de la línea de bienestar mínimo como resultado de los incentivos que el ingenio les ofrece a los productores de cańa; sin embargo, por la baja rentabilidad del cultivo, los productores obtienen ingresos moderados que no les permite superar al $100 \%$ la línea de bienestar mínimo. Bahena y Tornero (2009) reportan resultados similares en un diagnóstico de las unidades de producción familiar en pequeña irrigación en la subcuenca del río Yautepec, en Morelos, México.

El segundo cultivo de mayor importancia desde punto de vista del uso eficiente de la energía en la zona de riego fue el maíz (Cuadro 4); este bajo balance energético se debe a que el sistema de producción bajo riego presenta un uso excesivo de insumos y maquinaría. De acuerdo con Alemán y Brito (2003), en la producción de maíz se incurre en considerables gastos energéticos cuando se sigue un modelo tipo "revolución verde". La eficiencia económica del maíz bajo riego fue de $1.48 \pm 2.56$ como resultado de un rendimiento relativamente mayor que en la zona de
4, it presented the highest values of efficient use of energy, results that are similar to those reported by Markos (2007) with sugar cane as a crop of high energy production. The efficiency of these is high, in relation to the efficiency shown by other production systems, such as those with fruit trees, which is close to one (Gliessman, 2001). Sugar cane has a low productivity and, therefore, the producer obtains moderate income from this activity in the AES; this crop contributes with $\mathrm{e} 0.61 \pm 0.42$ of the proportion of coverage of the line of minimum welfare as a result of the incentives that the sugar plant offers sugar cane producers; however, because of the low profitability of the crop the producers obtain moderate income that does not allow them to exceed at $100 \%$ the line of minimum welfare. Bahena and Tornero (2009) report similar results in a diagnosis of the family production units under small-scale irrigation in the sub-basin of the Yautepec River, in Morelos, México.

The second crop of greatest importance from the point of view of the efficient use of energy in the irrigation zone was maize (Table 4); this low energetic balance is because the production system under irrigation presents an excessive use of inputs and machinery. According to Alemán and Brito (2003), in maize production there are considerable energetic expenses when a "green revolution" type model is followed. The economic efficiency of maize under irrigation was $1.48 \pm 2.56$ as a result of a relatively higher yield than in the hill zone; that of rainfed areas presented values of efficient use of energy of $1.28 \pm 0.89$, that is, 1.48 under what was obtained in the irrigation zone and economic efficiency of $0.61 \pm 0.42$, as response to the low yields. Ramírez et al. (2009) report that those obtained under rainfed conditions are quite low due to the use of materials of low potential, deficiencies in the plant's nutrition, and lack of sufficient moisture. In the AES, where the totality of the surface is subject to very erratic rainy

Cuadro 4. Relación en el uso eficiente de la energía, eficiencia económica, por zona y por actividad productiva, con la proporción de la cobertura de la línea de bienestar mínimo.

Table 4. Rate in the efficient use of energy, economic efficiency, by zone and by productive activity, with the proportion of coverage of the line of minimum welfare.

\begin{tabular}{lcccc}
\hline \multirow{2}{*}{ Actividad } & \multicolumn{2}{c}{ Lomerío } & \multicolumn{2}{c}{ Riego } \\
\cline { 2 - 5 } & Uso eficiente de la energía & Eficiencia económica & Uso eficiente de la energía & Eficiencia económica \\
\hline Ganadería bovina & $0.93 \pm 1.83$ & $2.17 \pm 3.27$ & $0.81 \pm 2.31$ & $3.91 \pm 4.73$ \\
Caña de azúcar & - & - & $16.73 \pm 11.04$ & $0.37 \pm 0.48$ \\
Maíz & $1.28 \pm 0.89$ & $0.61 \pm 0.42$ & $2.76 \pm 3.07$ & $1.48 \pm 2.56$ \\
\hline
\end{tabular}


lomerío; el de temporal presentó valores del uso eficiente de la energía de $1.28 \pm 0.89$, es decir 1.48 por debajo del obtenido en la zona de riego y eficiencia económica de $0.61 \pm 0.42$, como respuesta a los bajos rendimientos. Ramírez et al. (2009) reportan que los obtenidos en condiciones de temporal son muy bajos debido al uso de materiales de bajo potencial, deficiencias en la nutrición de la planta y a la falta de humedad suficiente. En los AES, donde la totalidad de la superficie está sujeta a temporales muy erráticos, es frecuente que entre $40 \%$ y $50 \%$ de la superficie sembrada se pierda total o parcialmente.

En relación con la ganadería bovina, este sistema productivo presentó una baja eficiencia en el uso de la energía tanto en la zona de lomerío $0.93 \pm 1.83$ como en la de riego $0.81 \pm 2.31$, debido a que se realiza la cría de ganado bovino de doble propósito con alimentación basada en pastoreo más residuos de maíz, o solo pastoreo, que no permite una adecuada transformación de los insumos en productos (Leche y carne). Al caracterizar el recurso genético animal en el diseño de sistemas sustentables de producción bovina en el trópico, Magaña et al. (2009) indican que lo ideal es que la vaca convierta eficientemente la energía del alimento en productos vendibles, como leche y kilogramos de becerro, lo que se puede alcanzar con cambios en el manejo alimenticio. Bacab-Pérez y Solorio-Sánchez (2011) reportaron la producción de leche en ganado de doble propósito manejado en sistemas silvopastoriles en Tepalcatepec, Michoacán, donde en el sistema tradicional las vacas recibieron $8 \mathrm{~kg}$ animal ${ }^{-1} \mathrm{día}^{-1} \mathrm{de}$ alimento concentrado durante la lactancia y sólo 1.5 $\mathrm{kg}$ animal $^{-1}$ día $^{-1}$ en los sistemas silvopastoriles; sin embargo, la producción de leche en los ranchos silvopastoriles fue 9.0 y $9.2 \mathrm{~kg}$ animal $^{-1} \mathrm{día}^{-1}$, y en el tradicional $10.4 \mathrm{~kg}_{\text {animal }}{ }^{-1}$ día $^{-1}$.

En ambas zonas la ganadería fue el sistema producto que reflejó mayor eficiencia económica, con valores del índice de $3.91 \pm 4.73$ para la zona de riego y para la de lomerío. En la mayoría de las unidades de producción no existe un gasto elevado de producción por la baja tecnología aplicada en el manejo sanitario y en la alimentación con el uso de recursos fibrosos como componente principal de la dieta, resultado que concuerda con lo reportado en varios estudios en sistemas de producción de doble propósito (Corro et al. 1996; Herrera et al.. 2008; Orantes Zebadúa et al. 2014). En un estudio sobre la respuesta productiva de vacas doble propósito en pastoreo sobre seasons, it is frequent to find that between $40 \%$ and $50 \%$ of the surface sown is lost totally or partially.

In relation to cattle production, this productive system presented a low efficiency in the use of energy both in the hill zone $0.93 \pm 1.83$ as under irrigation $0.81 \pm 2.31$, because double-purpose cattle breeding is carried out with feeding based on grazing plus maize residues, or only grazing, which does not allow an adequate transformation of inputs into products (milk or meat). When characterizing the animal genetic resource in the design of sustainable cattle production systems in the tropics, Magaña et al. (2009) indicate that the ideal situation is for the cow to convert efficiently the energy from food into sellable products, such as milk and kilograms of calf, which can be achieved with changes in the dietary management. Bacab-Pérez and SolorioSánchez (2011) report milk production in doublepurpose cattle managed in forest-grazing systems in Tepalcatepec, Michoacán, where the cows received $8 \mathrm{~kg}$ animal $^{-1}$ day $^{-1}$ of concentrate meal during lactating in the traditional system, and only 1.5 $\mathrm{kg}$ animal $^{-1}$ day $^{-1}$ in the forest-grazing systems; however, milk production in the forest-grazing ranches was 9.0 and $9.2 \mathrm{~kg}$ animal ${ }^{-1}$ day $^{-1}$, and in the traditional ones $10.4 \mathrm{~kg}$ animal ${ }^{-1} \mathrm{day}^{-1}$.

In both zones livestock production was the product system that reflected highest economic efficiency, with index values of $3.91 \pm 4.73$ for the irrigation zone and for the hill zone. In most of the production units there is not a high expenditure in production as a result of the low technology applied in the sanitary management and in the diet with the use of fibrous resources as the main component in the diet, result that agrees with what was reported in several studies in double-purpose production systems (Corro et al. 1996; Herrera et al.. 2008 and Orantes et al.. 2014). In a study about the productive response of double-purpose cows under grazing of sorghum shoots (Sorghum bicolor) and supplemented with a liquid diet based on cuji (Acacia macracantha) and phosphate urea, Espinoza et al. (2009) report that as far as the producer performs a small investment, the production of the herd is increased favorably. Double-purpose livestock production is the activity that has greatest incidence on the proportion of coverage of the line of minimum welfare in the hill zone $0.33 \pm 0.51$, considering that, in most cases, in the rural zones of México livestock production has the 
soca de sorgo (Sorghum bicolor) y suplementadas con dieta líquida a base de cují (Acacia macracantha) y urea fosfato, Espinoza et al. (2009) reportan que con que el productor realice una pequeña inversión, la producción del rebaño se incrementa favorablemente. La ganadería de doble propósito es la actividad que tiene mayor incidencia en la proporción de cobertura de la línea de bienestar mínimo en la zona de lomerío $0.33 \pm 0.51$, considerando que, en la mayoría de los casos, en las zonas rurales de México, la ganadería tiene como función el ahorro familiar, que se transforma rápidamente en dinero y permite enfrentar contingencias en el hogar y en la unidad de producción, lo que concuerda con lo reportado por Reyes y Gijón (2007) en un estudio sobre desarrollo rural, migración internacional y escasez de mercado en México.

En relación con las zonas, es evidente que existe una mayor eficiencia en el uso de la energía y de eficiencia económica en la zona de riego (Cuadro 4) como resultado del uso de fertilización, semillas mejoradas y de la aplicación de riego, evitando así el estrés hídrico a las plantas; por el contrario, en la zona de lomerío con condiciones climáticas erráticas, el uso semillas criollas y pastos de mediana a baja calidad (en la mayoría de los casos) no es posible obtener una adecuada productividad. Resultados que coinciden con lo reportado por Vilaboa (2012) indican que existen limitaciones sociales, económicas, productivas y sociales que limitan el desarrollo de la localidad de Angostillo, siendo esta representativa de la zona de lomerío del municipio Paso de Ovejas.

\section{Variables que determinan la proporción de cobertura (Pcober) de la línea de bienestar mínimo (LBM) y el autoconsumo}

El $74.08 \%$ de los productores no logran ingresos a través de las actividades agropecuarias en los AES que les permitan superar la línea de bienestar. Estos resultados están muy por encima de los reportados por CONEVAL (2014), quienes indican que el porcentaje de población con ingresos inferiores a la línea de bienestar pasó de $52.6 \%$ a $58 \%$ de 2012 a 2014 para el estado de Veracruz.

La correlación canónica entre los dos grupos de variables canónicas sociales o dependientes y las independientes mostró que existe una correlación significativa, explicando $83 \%$ de la variabilidad. Los pesos function of family savings, which transforms quickly into money and allows facing contingencies in the household and the production unit, which agrees with what was reported by Reyes and Gijón (2007) in a study about rural development, international migration and market scarcity in México.

Regarding the zones, it is evident that there is a greater efficiency in the use of energy and economic efficiency in the irrigation zone (Table 4) as a result of using fertilization, improved seeds, and of applying irrigation, thus avoiding hydric stress in the plants; on the contrary, in the hill zone with erratic climatic conditions, the use of Creole seeds and grasses of medium to low quality (in most of the cases), it is not possible to obtain an adequate productivity. These results agree with what was reported by Vilaboa (2012), which indicate that there are social, economic, productive and social limitations that restrict the development of the locality of Angostillo, with it being representative of the hill zone in the municipality of Paso de Ovejas.

\section{Variables that determine the proportion of coverage (Pcober) of the line of minimum welfare (LMW) and auto-consumption}

Of the producers, $74.08 \%$ do not attain income through the agricultural and livestock activities in the AES to allow them to overcome the welfare line. These results are well above those reported by CONEVAL (2014), which indicates that the percentage of population with income lower than the line of welfare went from $52.6 \%$ to $58 \%$ from 2012 to 2014 for the state of Veracruz.

The canonical correlation between the two groups of social or dependent canonical variables and the independent ones showed that there is a significant correlation, explaining $83 \%$ of the variability. The canonical weights of the first correlation point out that economic efficiency, economic productivity per man hours, and the agricultural/livestock biodiversity index have a low correlation (Figure 1).

Figure 1 shows that to the degree that the variables $\left(U_{1}\right)$ : efficient use of energy, energetic productivity per money invested, economic productivity per energy invested, zone and surface, increases, the percentage of coverage of the line of minimum welfare also increases; this is entirely logical, since the purchasing power of the producer 
canónicos de la primera correlación señalan que la eficiencia económica, la productividad económica por horas hombre y el índice de biodiversidad agropecuaria tienen una baja correlación (Figura 1).

En la Figura 1 podemos observar que en la medida que las variables $\left(U_{1}\right)$ : uso eficiente de la energía, productividad energética por dinero invertido, productividad económica por energía invertida, zona y superficie se incrementan, también se incrementa el porcentaje de cobertura de la línea de bienestar mínimo, lo cual es completamente lógico, ya que se incrementa el poder adquisitivo del productor $y$, por ende, el productor logra alcanzar o supera línea de bienestar mínimo. Esto se puede observar en la zona de lomeríos, donde en los AES de maíz se mantiene un uso moderado de la eficiencia energética pero, al complementarse con la eficiencia económica de la cría de ganado bovino, esta conjugación de recursos ecológicos y productivos les permite a las familias cubrir la línea de bienestar mínimo. Por el contrario, cuando estas variables independientes $\left(\mathrm{U}_{1}\right)$ disminuyen se incrementa el autoconsumo en is also increased and, therefore, the producer manages to reach or overcome the line of minimum welfare. This can be observed in the hill zone, where a moderate use of the energetic efficiency in the maize AES is maintained, although, when complemented with the economic efficiency of cattle breeding, this conjugation of ecological and productive resources allows families to cover the line of minimum welfare. On the contrary, when these independent variables $\left(\mathrm{U}_{1}\right)$ decrease, autoconsumption in the AES increases (Figure 1), as a result of a reduction in the capacity to generate adequate income through agricultural/livestock activities in the AES.

\section{Conclusions}

In the municipality of Paso de Ovejas, the agroecosystems with greatest surface and with capacity for irrigation are directed towards sowing crops of high energetic yields, such as sugar cane in combination to cattle breeding in order to improve

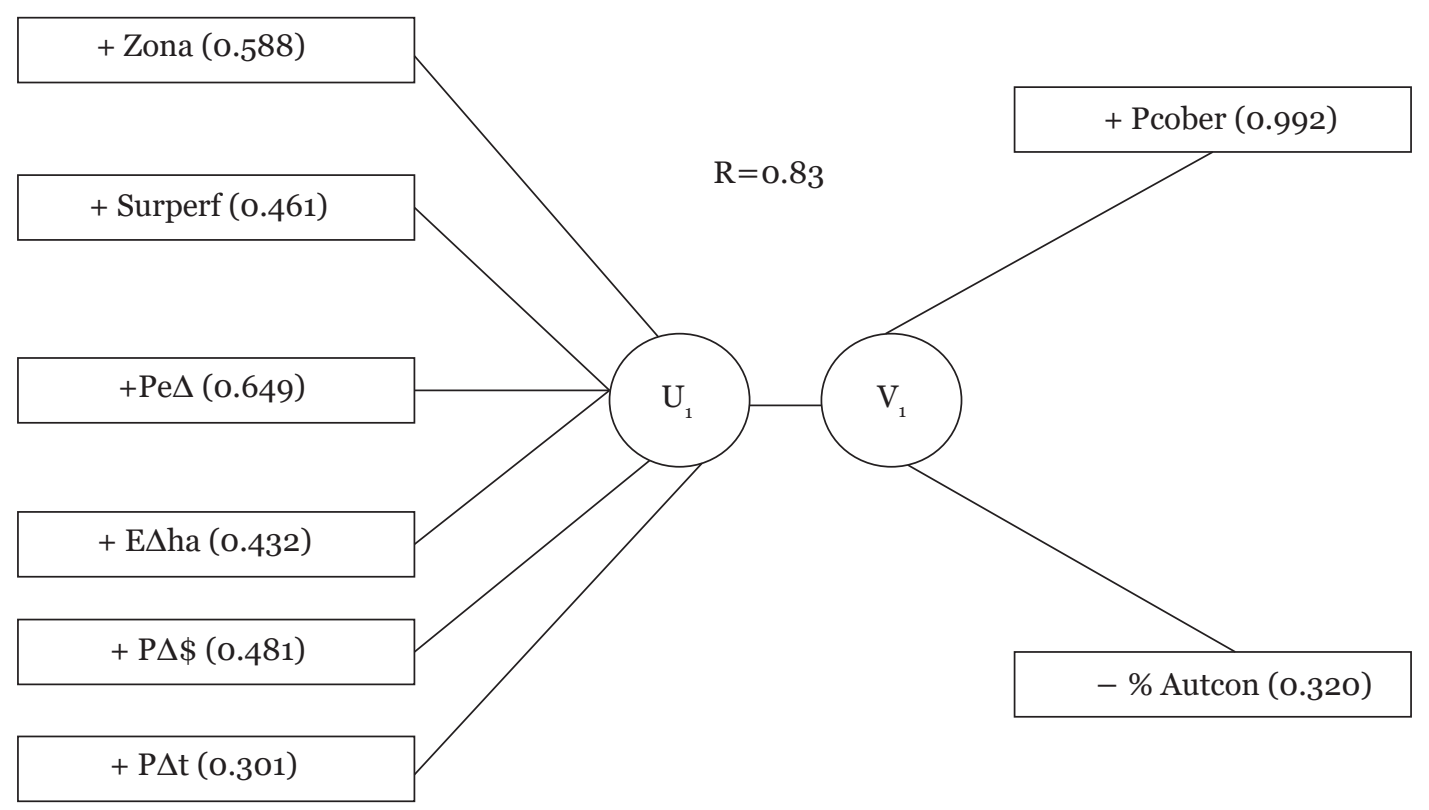

Figura 1. Patrón de asociación de la primera correlación canónica de la relación de la proporción de cobertura de la línea de pobreza y el porcentaje de autoconsumo de la familia rural, con los indicadores de eficiencia energética financiera y de productividad de los agroecosistemas. $U_{1}=$ Asociación de variables independientes. $V_{1}=$ Asociación de variables dependientes.

Figure 1. Pattern of association of the first canonical correlation of the rate of the proportion of coverage of the poverty line and the percentage of auto-consumption of the rural family, with the indicators of financial energetic efficiency and of productivity in the agroecosystems. $\mathrm{U} 1=$ Association of independent variables. $\mathrm{V} 1=$ Association of dependent variables. 
los AES (Figura 1), como resultado de una merma en la capacidad de generar ingresos adecuados a través de las actividades agropecuarias en los AE.

\section{Conclusiones}

En el municipio de Paso de Ovejas los agroecosistemas con mayor superficie y con capacidad de riego son orientados a la siembra de cultivos de altos rendimientos energéticos, como la caña de azúcar en combinación con la cría de ganado bovino para mejorar la eficiencia económica. Esta actividad productiva permite a la familia rural solventar situaciones económicas coyunturales, ya que funciona como un ahorro.

El sistema producto ganadería bovina es la actividad predominante en ambas zonas, presentando productividad y eficiencia energética baja, en contraparte con una mayor eficiencia económica resultado de un bajo uso de insumos y tecnología.

Los productores seleccionan la actividad productiva de acuerdo con la disponibilidad de recursos naturales y económicos, y combinan la caña de azúcar, que les permite una seguridad social, el maíz que representa una alta participación en el autoconsumo y la ganadería como fuente de ahorro familiar, con diferentes combinaciones que logran superar la línea de bienestar mínimo de la familia rural.

Es necesario establecer estrategias adecuadas para orientar al productor de la zona de temporal para que incremente su productividad, lo que le permitirá alcanzar la línea de bienestar mínimo.

\section{Agradecimiento}

Se agradecen los apoyos otorgados por: El Colegio de Postgraduados, a través del Campus Veracruz y la Línea Prioritaria de Investigación Agroecosistemas Sustentables, y El Instituto Tecnológico Superior de Tantoyuca, a través de su Director General M.C. Francisco J. Hernández Luna.

\section{Literatura Citada}

Alemán P., R., y J. Brito F. 2003. Balance energético en dos sistemas de producción de maíz (Zea mays L.) en las condiciones de Cuba. Agroecología. Centro Agrícola. 3:84-87.

Altieri M., P. Koohafkan, y E. Holt-Giménez. 2012. Agricultura verde: fundamentos agroecológicos para diseñar sistemas agrícolas biodiversos, resilientes y productivos. Agroecología 7(1):7-18. economic efficiency. This productive activity allows the rural family to afford critical juncture financial situations, since it functions as savings.

The cattle breeding production system is the predominant activity in both zones, presenting low productivity and energetic efficiency, as counterpart to a greater economic efficiency that results from a low use of inputs and technology.

The producers selected the productive activity according to the availability of natural and financial resources, and combine sugar cane, which allows them social security, maize that represents a high participation in auto-consumption, and livestock production as a source of family savings, with different combinations that manage to overcome the line of minimum welfare of the rural family.

It is necessary to establish adequate strategies to direct the producer from the rainfed zone to increase his productivity, which will allow him to reach the line of minimum welfare.

- End of the English version -

Bacab-Pérez, M., y F. Solorio-Sánchez, 2011. Oferta y consumo de forraje y producción de leche en ganado de doble propósito manejado en sistemas silvopastoriles en Tepalcatepec, Michoacán. Tropical and Subtropical Agroecosystems. Disponible en: http://www.redalyc.org/articulo.oa?id=93920942003

Bahena D., G., y M. Tornero C. 2009. Diagnóstico de las unidades de producción familiar en pequeña irrigación en la subcuenca del Río Yautepec, Morelos. Economía, Sociedad y Territorio. El Colegio Mexiquense, A.C. Toluca, México. 9(29):165-184.

Boltvinik J., y A. Marín. 2003. La canasta normativa de satisfactores esenciales de la Coplamar. Génesis y desarrollos recientes. Comercio Exterior. 53(5):473-484

Brunett P., L, C. González E., y L. García H. 2005. Evaluación de la sustentabilidad de dos agroecosistemas campesinos de producción de maíz (Zea mays L.) y leche, utilizando indicadores. Livestock Research for Rural Development. Disponible en: http://www.lrrd.org/lrrd17/7/pere17078.htm

CEPAL (Comisión Económica para América Latina y el Caribe). 2013a. Panorama fiscal de América Latina y el Caribe. Reformas tributarias y renovación del pacto fiscal, Santiago de Chile. Disponible en: http://repositorio.cepal.org/handle/11362/3097

CEPAL (Comisión Económica para América Latina y el Caribe). 2013b. Panorama Económico y Social de la Comunidad de Estados Latinoamericanos y Caribeńos. Santiago de Chile. Disponible en: http://repositorio.cepal.org/handle/11362/35917

Cirujeda A., C Zaragoza, J. Aibar. 2008. Factores que Influyen en la Biodiversidad de la Flora Arvense de los Cereales. In: VIII CONGRESO SEAE sobre: Cambio climático, biodi- 
versidad y desarrollo rural sostenible. Bullas. Murcia. España. Disponible en: http://hdl.handle.net/10532/3132

CONEVAL (Consejo Nacional de Evaluación de la Política de Desarrollo Social). 2014. Informe de resultados de la medición de pobreza 2014. Disponible en: http://www.coneval. org.mx/SalaPrensa/Documents/Comunicado005_Medicion_pobreza_2014.pdf

Corro M., M., R. Ochoa, L. Galindo R., y A. Aluja S. 1996. Evaluación económica de fincas de doble propósito en la región Centro-Norte de Veracruz. In: Reunión Nacional de Investigación Pecuaria. Cuernavaca. Morelos. INIFAP.

Denoia J., M. S. Vilche, S. Montico, B. Tonel, y N. Di Leo. 2006. Análisis descriptivo de la evolución de los modelos tecnológicos difundidos en el Distrito Zavalla (Santa Fe) desde una perspectiva energética. Ciencia, Docencia y Tecnología 33:209-226.

Espinoza F., Y. Díaz, V. Hidalgo, L. Folache, y J. Palma 2009. Respuesta productiva de vacas doble propósito pastoreando soca de sorgo (Sorghum bicolor) y suplementadas con dieta líquida a base de cují (Acacia macracantha) y ureafosfato. Zootecnia Tropical. Maracay. 27(3):233-238.

FAO (Organización de la Naciones Unidas para la Alimentación y la Agricultura). 2015. Recomendaciones finales del Seminario Regional sobre Agroecología en América Latina y el Caribe. Disponible en: http://www.fao.org/3/a-au442s.pdf

Gallardo-López, F., D. Riestra D., A. Aluja-Schunemann, y J. Martínez-Dávila. 2002. Factores que determinan la diversidad agrícola y los propósitos de producción en los agroecosistemas del Municipio de Paso de Ovejas, Veracruz, México. Revista Agrociencia 36(4):495-502.

García E. 2004. Modificaciones al Sistema de Clasificación Climática de Köppen para Adaptarlo a las Condiciones de la República Mexicana. México. Instituto de Geografía. UNAM. 98 p.

Gliessman S., R. 2001. Agroecologia; processos ecológicos em agricultura sustentável. Ed. Universidade/UFRSGS, 2.Ed. Porto Alegre. 18:509-533.

González de M., M. 2011. Algunas notas sobre agroecología y política. Agroecología. 6:9-21

González M., O., y B. Meneses A. 2015. El abandono de la política económica en la actividad agrícola: el caso de la pobreza rural en Veracruz, México como posible consecuencia (20002012). Ciencia Administrativa. 1:159-169.

Herrera P., B. Birbe, O. Colmenares, R. Hernández, C. Bravo, y D. Hernández. 2008. Sistemas de producción con ganadería de doble propósito en condiciones de sabanas bien drenadas. Acta Biológica Venezuelica. 28(1):29-38.

INAFED (Instituto Nacional para el Federalismo y Desarrollo Municipal). 2002. Enciclopedia de los Municipios y Delegaciones de México. Disponible en: http://www.inafed.gob. $\mathrm{mx} /$ work/enciclopedia/index.html

Jiménez J., R., A. Pesado F., L. García H., L. Dávalos F., V. Espinosa O., y A. Ducoing W. 2008. Persistencia de la lechería familiar en el municipio de Maravatío Michoacán. Disponible en: http://www.lrrd.org/lrrd20/10/jime20153.htm

Leite S. 2004. Autoconsumo y sostenibilidad en la agricultura familiar: una aproximación a la experiencia brasileña. In: Políticas de seguridad alimentaria y nutrición en América Latina (comp), ED. HUCITEC FAO-FODEPAL. Sao Paulo.

Magańa J., G., G. Parra-Bracamonte, R. Estrada-León, J. KuVera, y C. Sosa-Ferreyra. 2009. Caracterización del recur- so genético animal en el diseño de sistemas sustentables de producción bovina en el trópico. Tropical and Subtropical Agroecosystems. 10:85-94.

Marín, A. 2002. La medición de la pobreza. Una nueva aproximación. Tesis de licenciatura en Economía, Universidad Tecnológica de México.

Markos A. 2007. Agrocombustibles: impactos sobre el ambiente, la soberanía y la seguridad alimentaria global. Disponible en: http://www.biodiversidadla.org/content/view/full/33604

Mora-Delgado, J., C. Ramírez Martínez, y O. Quiros Madrigal. 2007. Mano de obra, análisis beneficio-costo y productividad de la energía en la caficultura campesina de Puriscal, Costa Rica. Cuadernos de Administración. 20(33):79-101.

Orantes-Zebadúa, M., D Platas-Rosado, V. Córdova-Avalos, M. De los Santos-Lara, y A. Córdova-Avalos. 2014. Caracterización de la ganadería de doble propósito en una región de Chiapas, México. Ecosistemas y recursos agropecuarios. 1(1):49-58.

Parra U., G. 1989. Zonificación agroecológica para la producción de caña de azúcar en algunos estados de México. Tesis de Maestría. Colegio de Postgraduados. Montecillo, México.

Perales H., F. Benz, B., and B. Brush, S. 2005. Maize diversity and ethnolinguistic diversity in Chiapas, Mexico. Proc. Natl. Acad. Sci. U.S.A. 102:949-954.

Pimentel D. 1993. Economics and energetics of organic and conventional farming. Journal of Agricultural and Environmental Ethics. 6(1): 53-60.

Quintos R., J., y A. Quispe L. 2004. Estrategias de supervivencia de los productores agropecuarios en las áreas periurbanas de La Ciudad de México, el caso de San Andrés Mixquic y San Nicolás Tetelco. Comunicaciones en Socioeconomía, Estadística e Informática. 8(2):1-26.

Ramírez G., A. González, y L.Pérez. 2009. Maíz (Zea mays L.) de alta productividad en el estado de Yucatán. INIFAP. Campo Experimental Mocochá. Disponible en: http://www.fpy.org. $\mathrm{mx} /$ index.php?id=maizdealtoproductividad.

Rathke G.W., J. Wienhold B., W. Wilhelm W., and W. Diepenbrock. 2007. Tillage and rotation effect on corn- soybean energy balances in eastern Nebraska. Soil Tillage Res. 97: 60-70.

Reyes M., R., y A. Gijón C. 2007. Desarrollo rural, migración internacional y escasez de mercados financieros en México. Trace. Travaux et recherches dans les Amériques du Centre. 52:45-62.

Salgado-Mora, M., G. Ibarra-Núñez, J. Macías-Sámano, y O. López-Báez. 2007. Diversidad arbórea en cacaotales del Soconusco, Chiapas, México. Interciencia. 32(11):763-768.

Scheaffer L, W. Mendenhall, y L. Ott.1987. Elementos de muestreo. Grupo Editorial Iberoamérica. México. 321p.

Shannon C., E., and W. Weaver. 1963. The Mathematical Theory of Communication. University of Illinois Press, Urbana. $117 \mathrm{p}$.

Statistica Stat-Soft Inc. 2003. User guides. 2325. East $13^{\text {th }}$ Street, Tulsa Ok.74104. USA.

Valdés N., D. Pérez, M. Márquez, L. Angarica, y D. Vargas. 2009. Funcionamiento y balance energético en agroecosistemas diversos. Cultivos Tropicales. 30(2):36-42.

Vilaboa A., J. 2012. Esquema de Vinculación del Campus Veracruz, Colegio de Postgraduados: La Microrregión de Atención Prioritaria Angostillo. Agroentorno 141:9-11. 